\title{
Short Term Effects of Antimicrobial Agent Triclosan on Oreochromis mossambicus (Peters, 1852): Biochemical and Genetic Alterations
}

Seenivasan Deepika1, Pandurengan Padmavathy ${ }^{1}$, Arasan Srinivasan ${ }^{1}$, Gopalrajan Sugumar ${ }^{2}$, Paulraj Jawahar ${ }^{3}$

10.18805/IJAR.B-4686

\begin{abstract}
Background: Triclosan is an antimicrobial agent which enters into the aquatic environment through wastewater discharges which causes potential health risk in human and aquatic organisms. The present study aimed to determine the toxic effects of triclosan on Oreochromis mossambicus.

Methods: The fishes were subjected to five different concentrations viz. 131, 262, 523, 1046 and $2092 \mu \mathrm{g} . \mathrm{I}^{-1}$ of triclosan for $96 \mathrm{~h}$ acute toxicity test. To evaluate the levels of enzymes such as acetylcholinesterase and glutathione $S$ transferase, brain and liver tissues were collected, homogenized, extracted and stored at $-20^{\circ}$ for further analysis. The DNA damage was assessed in gill and liver tissues using single cell gel electrophoresis method.

Result: In present study, the calculated $96 \mathrm{~h} \mathrm{LC}_{50}$ value of triclosan in 0 . mossambicus was $740 \mu \mathrm{g} . \mathrm{I}^{-1}$ and the fishes showed various behavioural alterations. Time and dose dependent inhibition of AChE activity in brain tissue was observed during acute toxicity test. However, the GST activity in liver tissue increased on exposure to triclosan with significant increase in concentration of toxicant. DNA damage index was higher in gill tissue compared to the liver tissue during acute exposure to TCS which could cause detrimental effects in fishes.
\end{abstract}

Key words: Acute toxicity, DNA damage, Enzyme activity, Oreochromis mossambicus, Triclosan.

\section{INTRODUCTION}

In the modern world, anthropogenic pollution causes potential threat to aquatic ecosystem by interference in the normal metabolism, reproduction and development of aquatic organisms. Triclosan (TCS) (CAS registration number 3380-34-5) also known as 5-chloro-2-(2,4dichlorophenoxy) phenol or 2,4,4' -trichloro-2' -hydroxydiphenyl ether, is a broad-spectrum antimicrobial agent in some personal care products such as toothpastes, soaps, hand washes, deodorants, kitchen and plastic wares (Fang et al., 2010; Maclsaac et al. 2014). Its widespread use in homes and in health care centres is the reason that it has become a water micro-pollutant (Li et al. 2010; Helbing et al., 2011). Due to its high lipophilicity $\left(\log \mathrm{K}_{\text {ow }}=4.8\right.$ octanol - water partition coefficient), it has serious distress about bioaccumulation in fatty tissues which raises toxicity concern in aquatic organisms (Behera et al. 2011).

Toxicity study helps to understand the effects of environmental pollutants on aquatic organisms by bioassay methods (Srivastava et al., 2016). Biomarkers can provide biologically and ecologically relevant information and considered as a valuable tool for the establishment of guidelines for effective environmental management (Tashla et al., 2018). Acetylcholinesterase (AChE) is one of the most commonly used biomarker enzymes of neurotoxicity and found at neuromuscular junctions and cholinergic synapses at the central nervous system. Main role of AChE is to
'Department of Aquatic Environment Management, Fisheries College and Research Institute, Tamil Nadu Dr. J.Jayalalithaa Fisheries University, Thoothukudi-628 008, Tamil Nadu, India.

2Department of Fish Processing Technology, Fisheries College and Research Institute, Tamil Nadu Dr. J. Jayalalithaa Fisheries University, Thoothukudi-628 008, Tamil Nadu, India.

${ }^{3}$ Department of Fisheries Biology and Resource Management, Fisheries College and Research Institute, Tamil Nadu Dr. J.Jayalalithaa Fisheries University, Thoothukudi-628 008, Tamil Nadu, India.

Corresponding Author: Seenivasan Deepika, Department of Aquatic Environment Management, TNJFU- Fisheries College and Research Institute, Tamil Nadu Dr. J.Jayalalithaa Fisheries University, Thoothukudi-628 008, Tamil Nadu, India.

Email: deepikanarmi@gmail.com

How to cite this article: Deepika, S., Padmavathy, P., Srinivasan, A., Sugumar, G. and Jawahar, P. (2021). Short Term Effects of Antimicrobial Agent Triclosan on Oreochromis mossambicus (Peters, 1852): Biochemical and Genetic Alterations. Indian Journal of Animal Research. DOI: 10.18805/IJAR.B-4686.

Submitted: 22-06-2021 Accepted: 20-08-2021 Online: 24-09-2021

regulate the nerve impulse transmission by hydrolysis of the neurotransmitter acetylcholine (Lionetto et al. 2013). Xenobiotics entering the aquatic environment can inhibit the AChE activity in brain which can lead to the behavioural 
alteration of fish (Ghazala et al., 2016). Some researchers have identified the reduction of AChE activity in the brain tissue due to TCS in Danio rerio, Pangasionodon hypothalamus, Cyprinus carpio, Ctenopharyngodon idella, Labeo rohita and Cirrhinus mrigala which was found to be more intense during the early life stages (Oliveira et al. 2009; Sahu et al., 2018; Dar et al., 2020). Glutathione Stransferase (GST) is the multifunctional phase II intracellular enzyme involves in detoxification of endogenous and exogenous toxic compounds. Pollutants are known to inhibit GST activity in aquatic organisms. Elevated level of GST activity in the tissues indicates increase in the biotransformation process of toxic metabolites for excretion (Modesto and Martinez, 2010). Genotoxicity study using comet assay is a most sensitive and economical technique to detect the genetic damage at cellular level. Comet assay is a versatile and simple way of evaluating the damage caused by the pollutants by measuring the breaks in the DNA chain of animal cell (de Lapuente et al. 2015). Therefore, the above biochemical and genetic parameters were chosen for the present study to evaluate the acute toxicity of TCS in Oreochromis mossambicus which is the commercially important and candidate species for aquaculture in food security point of view.

\section{MATERIALS AND METHODS Experimental fish}

Experimental fish O. mossambicus (weight: $102.75 \pm 2.63 \mathrm{~g}$; length: $15.73 \pm 0.68 \mathrm{~cm}$ ) was procured from the freshwater farm facility of Fisheries College and Research Institute, Thoothukudi, Tamil Nadu, India and the study was conducted during the year 2019. The fishes were acclimatized to the laboratory condition in fibreglass reinforced plastic (FRP) rectangular tank of 500 L capacity with proper water exchange and aeration. During the acclimatization the fishes were fed with commercial fish feed. The ethical guidelines for the animal care of the institute were strictly followed during the experiment.

\section{Chemicals}

Triclosan or 2, 4, 4' - Trichloro - 2' - hydroxydiphenyl ether (CAS id: 3380-34-5) was purchased from Tokyo Chemical Industry Co., Ltd. (purity >98\%) and used for the present study. Stock solution of $200 \mathrm{ppm}$ was prepared for the toxicity study using $0.01 \mathrm{~N} \mathrm{NaOH}$ solution as solvent for dissolving the TCS.

\section{Test conditions}

Water quality parameters of the water used for all the experiments viz. water temperature, $\mathrm{pH}$, dissolved oxygen, alkalinity and hardness were analysed during the toxicity study according to standard methods of APHA (2012). Static renewal test was followed for the acute and sublethal toxicity experiments. The test solutions were totally renewed at 24 $\mathrm{h}$ interval during the experimental period. The tests were conducted in duplicate in plastic tanks of $50 \mathrm{~L}$ capacity and ten fishes per tank were used for different concentrations of test chemical, solvent control $(0.01 \mathrm{~N} \mathrm{NaOH})$ and blank control. All experiments were conducted in indoor area with natural $12 \mathrm{~h}: 12 \mathrm{~h}$ light - dark photoperiod. Before $96 \mathrm{~h}$ acute toxicity test, the toxicity range - finding test was conducted for $48 \mathrm{~h}$ by following the method of EPA (2002). Randomly selected fishes were exposed to the test concentrations in logarithmic series (i.e. $0.01,0.1,1.0,10$ and $100 \mathrm{mg.l}^{-1}$ ) along with solvent and blank control.

\section{Acute toxicity test}

Based on the result of range - finding test, five experimental concentrations of TCS for O. mossambicus $(131,262,523$, 1046 and $2092 \mu \mathrm{g} . \mathrm{l}^{-1}$ ) was selected to conduct $96 \mathrm{~h}$ acute toxicity test and determined the median lethal concentration $\left(\mathrm{LC}_{50}\right)$ of TCS. Control group (toxicant free group) of fishes were maintained as the reference group for comparison with solvent ( $\mathrm{NaOH}$ group) and TCS exposed fishes. During the entire test period no feed was offered to the fishes. The physico chemical parameters of the test conditions were monitored daily for $96 \mathrm{~h}$ of the test period. Behavioural changes and fish mortality were monitored for $96 \mathrm{~h}$ and the dead animals were removed from the test conditions immediately to prevent contamination. The $\mathrm{LC}_{50}$ values were calculated using the mortality data by probit analysis (Finney, 1971).

\section{Collection of tissues and preparation of homogenates}

After $96 \mathrm{~h}$ of exposure to TCS in acute toxicity test the organs such as gill, liver and brain were collected from each treatment and control group of fishes. The collected organs were homogenised with $0.25 \mathrm{M}$ sucrose buffer solution (1:10 $\mathrm{w} / \mathrm{v})$. The homogenates were centrifuged at $14,000 \times \mathrm{g}$ for $15 \mathrm{~min}$ at $4 p^{\circ} \mathrm{C}$ to obtain supernatants which were used for further enzymatic analysis. All the supernatants were stored at $-20 \mathrm{p}^{\circ} \mathrm{C}$ until further analysis.

\section{Enzyme assay}

The activity of acetylcholinesterase (AchE; EC 3.1.1.7) was measured in brain tissue spectrophotometrically at $405 \mathrm{~nm}$ at $25 p^{\circ} \mathrm{C}$ according to the method of Ellman (1961) with some modifications described by Augustinsson (1957). The activity of AChE was expressed as $\mu \mathrm{M}$ of acetylcholine hydrolyzed $\mathrm{min}^{-1} \mathrm{mg}^{-1}$ of protein.

The activity of glutathione $S$ transferase (GST; EC 2.5.1.18) was measured in liver tissue at $340 \mathrm{~nm}$ spectrophotometrically at $25 \mathrm{p}^{\circ} \mathrm{C}$ according to Habig et al. (1974). The GST activity of liver following the formation of GSH conjugate with 1-chloro-2,4-dinitrobenzene (CDNB) was expressed as $\mathrm{n}$ mol. CDNB conjugates formed $\mathrm{min}^{-1}$ $\mathrm{mg}^{-1}$ of protein.

\section{Single cell gel electrophoresis (comet assay)}

The alkaline single cell gel electrophoresis (SCGE) / comet assay was performed in gill and liver tissues of tilapia 
Short Term Effects of Antimicrobial Agent Triclosan on Oreochromis mossambicus (Peters, 1852): Biochemical and Genetic Alterations

according to the standard procedure of Singh et al. (1988) with some modifications as described by Ali et al. (2008).

\section{Statistical analysis}

Differences in the test concentration and control were subjected to one way analysis of variance (ANOVA) followed by Turkey's multiple range test using statistical package SPSS 22.0. Difference in the mean range test and influence of TCS concentration in fishes were determined at $5 \%$ probability level. The results were presented as mean \pm standard error.

\section{RESULTS AND DISCUSSION Determination of $\mathrm{LC}_{50}$ and behavioural responses}

Triclosan has been classified as a class III drug (compounds with low permeability and high solubility) by FDA due to their broad spectrum antimicrobial activity (Dhillon et al., 2015). Toxicity studies conducted on various organisms proved that TCS is acutely and chronically toxic to all the organisms especially to the aquatic organism through wastewaters from different sources. Earlier studies observed the median lethal concentration $\left(\mathrm{LC}_{50}\right)$ of TCS on different fishes as $4400 \mu \mathrm{g} . \mathrm{l}^{-1}$ in Onchorynchus mykiss (AdolfssonErici et al., 2002), 370 and $1700 \mu \mathrm{g} . \mathrm{l}^{-1}$ in Oryzias latipes (Orvos et al., 2002 and Nassef et al., 2009), $340 \mu \mathrm{g} . \mathrm{l}^{-1}$ in Danio rerio (Oliviera et al, 2009), $1480 \mu \mathrm{g} . \mathrm{l}^{-1}$ in Xiphophorus helleri (Liang et al., 2013), $2810 \mu \mathrm{g.l}^{-1}$ in Oreochromis

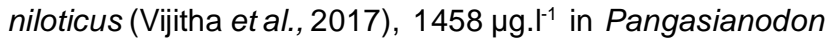

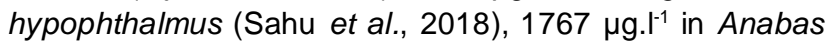
testudineus (Priyatha and Chitra, 2018), $360 \mu \mathrm{g} . \mathrm{I}^{-1}$ in Gibelion

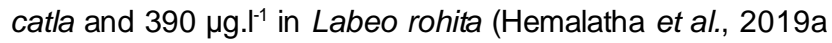
and $2019 \mathrm{~b}$ ). In the present study, the LC ${ }_{50}$ value of TCS on O. mossambicus was calculated based on the $96 \mathrm{~h}$ mortality data of fishes exposed to TCS. The data were plotted as graph and there was a positive correlation $(P<0.05)$ between the mortality of fishes and concentration of TCS (Fig 1). The calculated $96 \mathrm{~h} \mathrm{LC}_{50}$ value at $95 \%$ confidence limits for TCS for 0 . mossambicus was $740 \mu \mathrm{g} . \mathrm{I}^{-1}$. During the exposure period the fishes showed behavioural irregularities such as mucous formation, surfacing, erratic movement, air gulping, hanging at the top and discoloration of skin.

\section{Activity of acetylcholinesterase enzyme}

Acetylcholinesterase (AChE) activity is widely being used as a biomarker to study the neurotoxic effects of wide range of toxicants in the aquatic environment. Inhibition of AChE activity results in build up of acetylcholine which causes prolonged excitatory post synaptic potential which negatively impacts the overall behaviour and nervous system of fishes (Banaee et al., 2011). In the present study, the mean AChE activity of brain tissue of tilapia exposed to control medium was $0.345 \pm 0.01 \mu \mathrm{M} \cdot \mathrm{min}^{-1}$.mg.protein ${ }^{-1}$. In tilapia, on exposure to $96 \mathrm{~h}$ acute toxicity of TCS the AChE activity of the brain got significantly reduced to $0.266 \pm 0.03,0.209 \pm 0.02$, $0.175 \pm 0.01$ and $0.088 \pm 0.01 \mu \mathrm{M} \cdot \mathrm{min}^{-1} \cdot \mathrm{mg}$. protein ${ }^{-1}$ at 131 , 262,523 and $1046 \mu \mathrm{g} . \mathrm{I}^{-1}$ respectively (Fig 2). AChE activity in the brain tissue of tilapia was significantly $(p<0.05)$ reduced on exposure to different concentrations of TCS. There was no significant difference in enzyme activity between the control and solvent control group of tilapia in the acute toxicity test during the study period. The degree of reduction of enzyme activity was found to be increase with increase in concentration of TCS during the exposure. The reduction of AChE activity in tilapia on exposure to acute concentrations of TCS is shown in Fig 2. Highest amount of inhibition of AChE was observed at $1046 \mu \mathrm{g} . \mathrm{I}^{-1}$ of TCS in tilapia. Similar observation of reduction in enzyme activity in brain tissue was observed in zebra fishes by Oliviera et al. (2009) and Pullaguri et al. (2020).

\section{Activity of glutathione $S$ transferase}

Glutathione $S$ transferase is involved in detoxification of xenobiotics at cellular level and their activity in different organs acts as a potential biomarker in toxicity tests (Sturve et al, 2008). In the present study, the observed increase in concentration of GST enzyme in liver tissue can be attributed to the detoxification process of toxic metabolites and it is an indicator of defence mechanism (Modesto and Martinez, 2010; Sahu et al., 2018). The mean GST activity in liver tissue

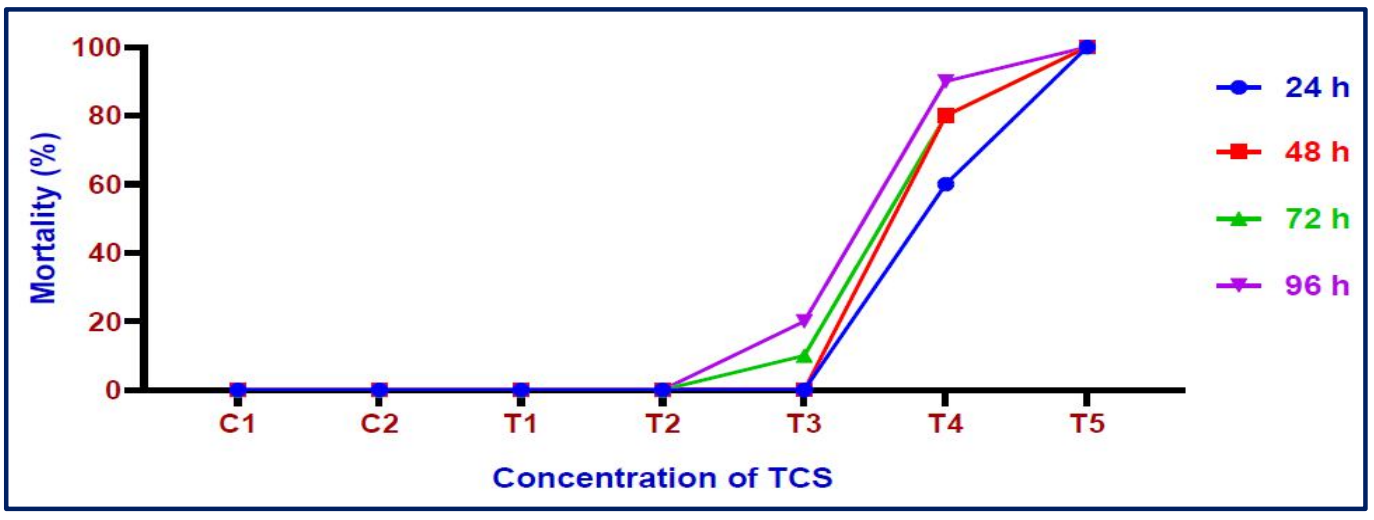

Fig 1: Mortality of Oreochromis mossambicus on exposure to different concentration of TCS.

C1 - Control; C2 - Solvent Control; T1 - 0.131 ppm; T2 - 0.262 ppm;

T3 - 0.523 ppm; T4 - 1.046 ppm; T5 - 2.092 ppm. 
of tilapia at control medium during acute toxicity test was 2.637 $\pm 0.13 \mathrm{n} \mathrm{mol}$. $\mathrm{min}^{-1} \mathrm{mg}$.protein ${ }^{-1}$. The GST activity was induced on exposure to TCS in fishes with significant increase in activity with increase in concentration of TCS. The GST activity on exposure to $96 \mathrm{~h}$ acute toxicity test significantly increased to $3.022 \pm 0.06,3.346 \pm 0.10$, $3.860 \pm 0.10$ and $3.551 \pm 0.10 \mathrm{n} \mathrm{mol}$. $\mathrm{min}^{-1} \mathrm{mg}$. protein ${ }^{-1}$ at 131 , 262, 523 and $1046 \mu \mathrm{g.} \mathrm{I}^{-1}$ respectively $(\mathrm{p}<0.05)$ (Fig 3). Similarly, an elevation in GST activity due to TCS toxicity were reported in zebra fish by Oliviera et al. (2009), in sword tail fish by Liang et al. (2013) and also in mussels and zooplankton (Canesi et al. 2007; Binelli et al., 2011; Peng et al., 2013; Han et al., 2016). GST inhibition at the early larval stages of Solea senegalensis observed by Araujo et al. (2019) proves that TCS inflicts more damage to fishes at their early life stages.

DNA damage in gill and liver of tilapia exposed to acute and sublethal toxicity of TCS

The integrity of DNA damage in blood cells and different tissues have been proved as potential biomarker for environmental toxicology. In the present investigation,

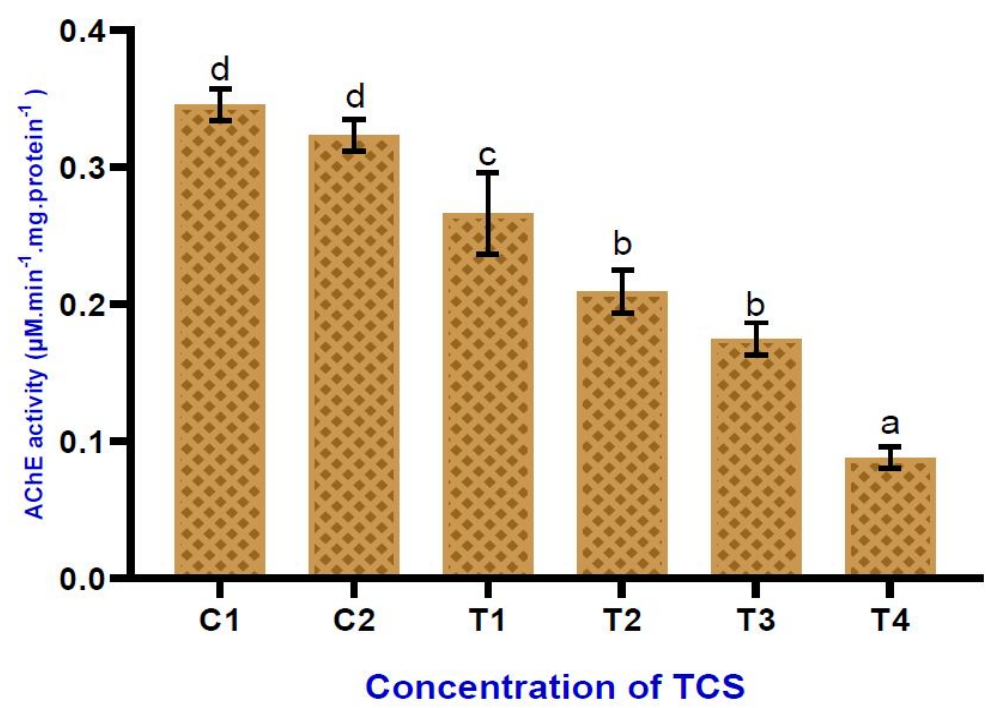

Fig 2: Mean acetylcholinesterase activity in O. mossambicus exposed to acute concentration of TCS for 96 h. [Superscripts indicate significant difference $(p<0.05)$ between control and different concentrations within the same exposure period. Error bars denote standard error $(n=3)]$.

C1 - Control; C2 - Solvent Control; T1 - 0.131 ppm; T2 - 0.262 ppm; T3 - 0.523 ppm; T4 - 1.046 ppm.

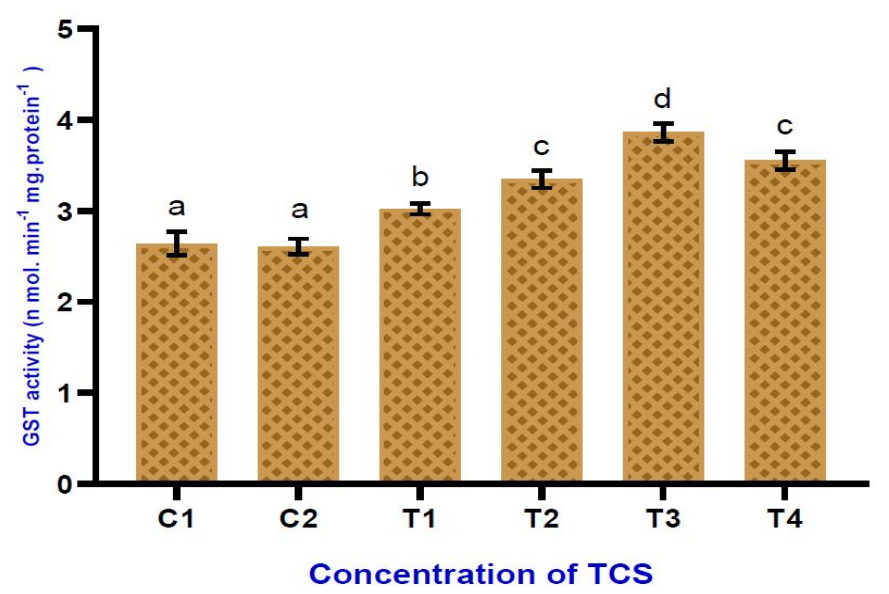

Fig 3: Mean glutathione $S$ transferase activity in O. mossambicus exposed to acute concentration of TCS for $96 \mathrm{~h}$. [Superscripts indicate significant difference $(p<0.05)$ between control and different concentrations within the same exposure period. Error bars denote standard error $(n=3)]$.

$$
\begin{gathered}
\text { C1 - Control; C2 - Solvent Control; T1 }-0.131 \text { ppm; T2 - } 0.262 \text { ppm; } \\
\text { T3 }-0.523 \text { ppm; T4 - } 1.046 \text { ppm }
\end{gathered}
$$




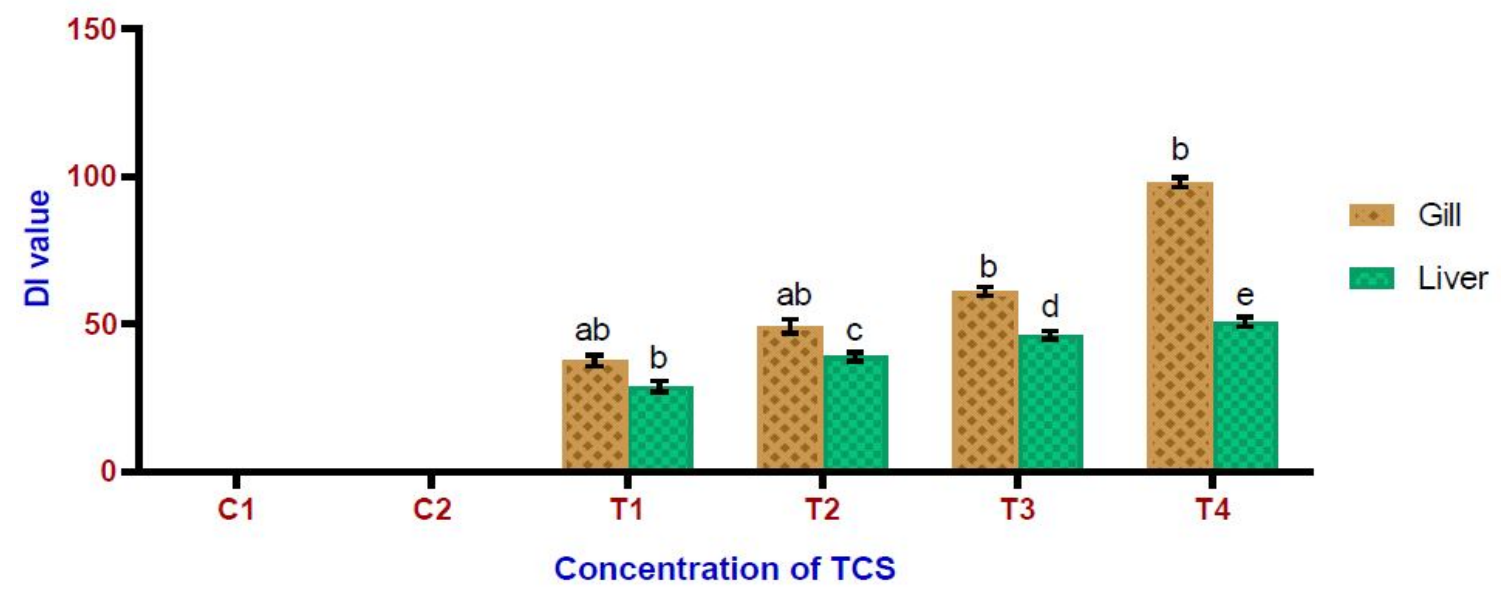

Fig 4: Mean DNA Damage Index (DI) in gill and liver of O. mossambicus exposed to acute concentration of TCS for $96 \mathrm{~h}$. [Superscripts indicate significant difference $(p<0.05)$ between control and different concentrations within the same exposure period.

Error bars denote standard error $(n=3)]$.

C1 - Control; C2 - Solvent Control; T1 - 0.131 ppm; T2 - 0.262 ppm;

T3 - 0.523 ppm; T4 -1.046 ppm.

significant dose dependent DNA damage intensity was recorded in gill and liver tissues of tilapia and rohu. The difference in extent of DNA damage in various tissues could be attributed to number of alkali - labile sites and variability in DNA of different tissues (Paul et al. 2019) because different cells have different levels of DNA single strand breaks due to variation in antioxidant concentration, metabolic and repair activity (Lee and Steinert, 2003). Effect of TCS on the index of DNA damage (DI) on gill and liver tissues of tilapia during acute toxicity test is presented in Fig 4. DNA damage was not observed in the control group of fishes in both gill and liver tissues of tilapia during $96 \mathrm{~h}$ acute toxicity test. In gill tissue, the mean DI values were observed as $37.564 \pm 1.92,49.275 \pm 2.34,61.005 \pm 1.47$ and $98.014 \pm 1.69$ at $96 \mathrm{~h}$ acute toxic concentrations of 131,262 , 523 and $1046 \mu \mathrm{g} . \mathrm{I}^{-1}$ respectively. In liver, the mean DI values at the concentrations of $131,262,523$ and $1046 \mu \mathrm{g} . \mathrm{I}^{-1}$ were $28.789 \pm 1.86,38.877 \pm 1.39,46.226 \pm 1.32$ and $50.705 \pm 1.58$ respectively. The DNA damage increased with increased in concentration of TCS in gill and liver tissue. The DI value was found to be higher in gill than the liver tissue. The TCS induced genotoxicity study on rainbow trout by Capkin et al. (2017) in red blood cells showed significant DNA damage. In addition to fishes, studies by Silva et al. (2015) and Xu et al. (2015) revealed the TCS induced DNA damage in live food organisms such as Daphnia magna and Artemia salina. So, the present investigation proved that TCS can affect the target tissue of fishes and induces DNA strand breakage.

\section{CONCLUSION}

The toxicity result of the investigation shows that it has the potential to affect the tilapia at the median lethal concentration of $740 \mu \mathrm{g} . \mathrm{I}^{-1}$ respectively. It also has the potential to affect the fishes biochemically and genetically.
The present detailed investigation on enzyme activity and DNA damage clearly showed that the TCS could alter the normal metabolic processes of the aquatic organisms. So, this preliminary study of TCS determination in fishes would gain interest in regular monitoring to obtain the contamination profile of emerging pollutants of personal care products. So, it is necessary to study in detail about the polluting agents of personal care products, their fate and transportation in the aquatic environment.

\section{REFERENCES}

Adolfsson Erici, M., Pettersson, M., Parkkonen, J. and Sturve, J. (2002). Triclosan, a commonly used bactericide found in human milk and in the aquatic environment in Sweden. Chemosphere. 46: 1485-1489.

Ali, D., Nagpure, N.S., Kumar, S., Kumar, R. and Kushwaha, B. (2008). Genotoxicity assessment of acute exposure of chlorpyrifos to freshwater fish Channa punctatus (Bloch) using micronucleus assay and alkaline single-cell gel electrophoresis. Chemosphere. 71(10): 1823-1831.

American Public Health Association (APHA) (2012). Standard methods for the Examination of Water and Wastewater. $\left(22^{\text {nd }} \mathrm{ed}\right)$, APHA, Washington, DC.

Araujo, C.V., Gomez, L., Silva, D.C., Pintado-Herrera, M.G., LaraMartin, P.A., Hampel, M. and Blasco, J. (2019). Risk of triclosan based on avoidance by the shrimp Palaemon varians in a heterogeneous contamination scenario: How sensitive is this approach. Chemosphere. 235: 126-135.

Augustinsson, K.B. (1957). Assay methods for cholinesterases. Methods of Biochemical Analysis. 5: 1-63.

Banaee, M., Sureda, A., Mirvaghefi, A.R. and Ahmadi, K. (2011). Effects of diazinon on biochemical parameters of blood in rainbow trout (Oncorhynchus mykiss). Pesticide biochemistry and physiology. 99(1): 1-6. 
Behera, S.K., Kim, H.W., Oh, J.-E. and Park, H.S. (2011). Occurrence and removal of antibiotics, hormones and several other pharmaceuticals in wastewater treatment plants of the largest industrial city of Korea. Science of the Total Environment. 409: 4351-4360.

Binelli, A., Parolini, M., Pedriali, A. and Provini, A. (2011). Antioxidant activity in the zebra mussel (Dreissena polymorpha) in response to triclosan exposure. Water, Air, and Soil Pollution. 217(1-4): 421-430.

Canesi, L., Lorusso, L.C., Ciacci, C., Betti, M., Regoli, F., Poiana, G., Gallo, G. and Marcomini, A. (2007). Effects of blood lipid lowering pharmaceuticals (bezafibrate and gemfibrozil) on immune and digestive gland functions of the bivalve mollusc, Mytilus galloprovincialis. Chemosphere. 69(6): 994-1002.

Capkin, E., Ozcelep, T., Kayis, S. and Altinok, I. (2017). Antimicrobial agents, triclosan, chloroxylenol, methylisothiazolinone and borax, used in cleaning had genotoxic and histopathologic effects on rainbow trout. Chemosphere. 182: 720-729.

Dar, O.I., Sharma, S., Singh, K., Sharma, A., Bhardwaj, R. and Kaur, A. (2020). Biochemical markers for prolongation of the acute stress of triclosan in the early life stages of four food fishes. Chemosphere. 247: 125914.

de Lapuente, J., Lourenço, J., Mendo, S.A., Borràs, M., Martins, M.G., Costa, P.M. and Pacheco, M. (2015). The Comet Assay and its applications in the field of ecotoxicology: A mature tool that continues to expand its perspectives. Frontiers in Genetics. 6.

Dhillon, G.S., Kaur, S., Pulicharla, R., Brar, S.K., Cledon, M., Verma, M. and Surampalli, R.Y. (2015). Triclosan: current status, occurrence, environmental risks and bioaccumulation potential. International Journal of Environmental Research and Public Health. 12(5): 5657-5684.

Ellman, G.L., Courtney, K.D., Andres Jr, V. and Featherstone, R.M. (1961). A new and rapid colorimetric determination of acetylcholinesterase activity. Biochemical pharmacology, 7(2): 88-95.

EPA (Environmental Protection Agency) (2002). Methods for Measuring the Acute Toxicity of Effluents and Receiving Waters to Freshwater and Marine Organisms, $5^{\text {th }}$ Edition. 275pp.

Finney, D.J. (1971). Probit Analysis, London Cambridge University Press, pp. 333.

Fang, J.L., Stingley, R.L., Beland, F.A., Harrouk, W., Lumpkins, D.L. and Howard, P. (2010). Occurrence, Efficacy, Metabolism and toxicity of triclosan. Journal of Environmental Science and Health, Part C. 28: 147-171.

Ghazala, G., Mahboob, S., Al-Ghanim, K.A., Sultana, S., Sultana, T., Al-Misned, F., Ahmed, L., Shahid, T. and Ahmad, Z. (2016). A study on chronic effect of profenofos on acetylcholinesterase and butyrylcholinesterase activities and protein contents in various tissues in major carps. African Journal of Traditional, Complementary and Alternative Medicines. 13: 54-59.

Habig, W.H., Pabst, M.J. and Jakoby, W.B. (1974). Glutathione Stransferases the first enzymatic step in mercapturic acid formation. Journal of biological Chemistry. 249(22): 71307139.
Han, J., Won, E.J., Hwang, U.K., Kim, I.C., Yim, J.H. and Lee, J.S. (2016). Triclosan (TCS) and Triclocarban (TCC) cause lifespan reduction and reproductive impairment through oxidative stress-mediated expression of the defensome in the monogonont rotifer (Brachionus koreanus). Comparative Biochemistry and Physiology Part C: Toxicology and Pharmacology. 185: 131-137.

Helbing, C.C., Propper, C.R. and Veldhoen, N. (2011). Triclosan affects the thyroid axis of amphibians. Toxicological Sciences. 123: 601-602.

Hemalatha, D., Nataraj, B., Rangasamy, B., Shobana, C. and Ramesh, M. (2019a). DNA damage and physiological responses in an Indian major carp Labeo rohita exposed to an antimicrobial agent triclosan. Fish Physiology and Biochemistry. 45: 1463-1484.

Hemalatha, D., Rangasamy, B., Nataraj, B. and Ramesh, M. (2019b). Assessment of triclosan impact on enzymatic biomarkers in an Indian major carp, Catla catla. The Journal of Basic and Applied Zoology. 80: 23.

Lee, R.F. and Steinert, S. (2003). Use of the single cell gel electrophoresis/comet assay for detecting DNA damage in aquatic (marine and freshwater) animals. Mutation Research/Reviews in Mutation Research. 544(1): 43-64.

Li, X., Ying, G.G., Su, H.-C., Yang, X.B. and Wang, L. (2010). Simultaneous determination and assessment of 4nonylphenol, bisphenol $\mathrm{A}$ and triclosan in tap water, bottled water and baby bottles. Environment International. 36: 557-562.

Liang, X., Nie, X., Ying, G., An, T. and Li, K. (2013). Assessment of toxic effects of triclosan on the swordtail fish (Xiphophorus helleri) by a multi-biomarker approach. Chemosphere. 90(3): 1281-1288.

Lionetto, M.G., Caricato, R., Calisi, A., Giordano, M.E. and Schettino, T. (2013). Acetylcholinesterase as a Biomarker in Environmental and Occupational Medicine: New Insights and Future Perspectives. BioMed Research International. 1-8.

Maclsaac, J.K., Gerona, R., Blanc, P.D., Apatira, L., Friesen, M., Coppolino, M. and Janssen, S. (2014). Healthcare worker exposures to the antibacterial agent triclosan. Journal of Occupational and Environmental Medicines. 56: 834839.

Modesto, K.A. and Martinez, C.B.R. (2010). Effects of Roundup Transorb on fish: Hematology, antioxidant defenses and acetylcholinesterase activity. Chemosphere. 81: 781-787.

Nassef, M., Matsumoto, S., Seki, M., Kang, I.J., Moroishi, J., Shimasaki, Y. and Oshima, Y. (2009). Pharmaceuticals and personal care products toxicity to Japanese medaka fish (Oryzias latipes). Journal of the Faculty of Agriculture, Kyushu University. 54(2): 407-411.

Oliveira, R., Domingues, I., Koppe Grisolia, C. and Soares, A.M.V.M. (2009). Effects of triclosan on zebrafish early-life stages and adults. Environmental Science and Pollution Research. 16: 679-688.

Orvos, D.R., Versteeg, D.J., Inauen, J., Capdevielle, M., Rothenstein, A. and Cunningham, V. (2002). Aquatic toxicity of triclosan. Environmental Toxicology and Chemistry. 21: 1338-1349. 
Paul, T., Shukla, S.P., Kumar, K., Poojary, N. and Kumar, S. (2019). Effect of temperature on triclosan toxicity in Pangasianodon hypophthalmus (Sauvage, 1878): Hematology, biochemistry and genotoxicity evaluation. Science of the total environment. 668: 104-114.

Peng, Y., Luo, Y., Nie, X.P., Liao, W., Yang, Y.F. and Ying, G.G. (2013). Toxic effects of triclosan on the detoxification system and breeding of Daphnia magna. Ecotoxicology. 22(9): 1384-1394.

Priyatha, C.V. and Chitra, K.C. (2018). Acute toxicity of triclosan on the native freshwater fish, Anabas testudineus (Bloch, 1792): Behavioral alterations and histopathological lesions. International Journal of Life Sciences. 6(1): 166-172.

Pullaguri, N., Nema, S., Bhargava, Y. and Bhargava, A. (2020). Triclosan alters adult zebrafish behavior and targets acetylcholinesterase activity and expression. Environmental Toxicology and Pharmacology. 75: 103311.

Sahu, V.K., Karmakar, S., Kumar, S., Shukla, S.P. and Kumar, K. (2018). Triclosan toxicity alters behavioral and hematological parameters and vital antioxidant and neurological enzymes in Pangasianodon hypophthalmus (Sauvage, 1878). Aquatic Toxicology. 202: 145-152.

Singh, N.P., McCoy, M.T., Tice, R.R. and Schneider, E.L. (1988). A simple technique for quantitation of low levels of DNA damage in individual cells. Experimental cell research. 175(1): 184-191.
Silva, A.R.R., Cardoso, D.N., Cruz, A., Lourenço, J., Mendo, S. Soares, A.M. and Loureiro, S. (2015). Ecotoxicity and genotoxicity of a binary combination of triclosan and carbendazim to Daphnia magna. Ecotoxicology and environmental safety. 115: 279-290.

Srivastava, S., Akkarakaran, J.J., Sounderajan, S., Shrivastava, M. and Suprasanna, P. (2016). Arsenic toxicity in rice (Oryza sativa L.) is influenced by sulfur supply: Impact on the expression of transporters and thiol metabolism. Geoderma, Integrated Management Strategies for Arsenic and Cadmium in Rice Paddy Environments. 270: 33-42.

Sturve, J., Almroth, B.C. and Forlin, L. (2008). Oxidative stress in rainbow trout (Oncorhynchus mykiss) exposed to sewage treatment plant effluent. Ecotoxicology and environmental safety. 70(3): 446-452.

Tashla, T., Zuza, M., Kenjves, T., Prodanovic, R., Solesa, D., Bursic, V., Petrovic, A., Pelic, D.L., Boskovic, J. and Puvaca, N. (2018). Fish as an important bio-indicator of environmental pollution with persistent organic pollutants and heavy metals. Journal of Agronomy. 28.

Vijitha, C.K., Asifa, K.P. and Chitra, K.C. (2017). Assessment of genotoxic and haematological consequence of triclosan in the fish, Oreochromis niloticus (Linnaeus, 1758). International Journal of Applied Research. 3(2): 101-109.

Xu, X., Lu, Y., Zhang, D., Wang, Y., Zhou, X., Xu, H. and Mei, Y. (2015). Toxic assessment of triclosan and triclocarban on Artemia salina. Bulletin of environmental contamination and toxicology. 95(6): 728-733. 